\title{
Wilson's disease in Southern Brazil: genotype-phenotype correlation and description of two novel mutations in ATP7B gene
}

\author{
Doença de Wilson no sul do Brasil: correlação genotípica-fenotípica \\ e a descrição de duas novas mutações no gene ATP7B \\ Ricardo Schmitt de Bem¹, Salmo Raskin², Dominique Araújo Muzzillo', Marta Mitiko Deguti², Eduardo Luiz \\ Rachid Cançado ${ }^{3}$, Thiago Ferreira Araújo4 ${ }^{4}$ Maria Cristina Nakhle ${ }^{4}$, Egberto Reis Barbosa ${ }^{5}$, Renato Puppi \\ Munhoz ${ }^{6}$, Hélio Afonso Ghizoni Teive ${ }^{6}$
}

\begin{abstract}
Objective: Wilson's disease (WD) is an inborn error of metabolism caused by abnormalities of the copper-transporting protein encoding gene ATP7B. In this study, we examined ATP7B for mutations in a group of patients living in southern Brazil. Methods: 36 WD subjects were studied and classified according to their clinical and epidemiological data. In 23 subjects the ATP7B gene was analyzed. Results: Fourteen distinct mutations were detected in at least one of the alleles. The c.3207C>A substitution at exon 14 was the most common mutation (allelic frequency $=37.1 \%$ ) followed by the c.3402delC at exon 15 (allelic frequency=11.4\%). The mutations c. $2018-2030$ del13 at exon 7 and c.4093InsT at exon 20 are being reported for the first time. Conclusion: The c.3207C>A substitution at exon 14, was the most common mutation, with an allelic frequency of $37.1 \%$. This mutation is the most common mutation described in Europe.
\end{abstract}

Key words: hepatolenticular degeneration, signs and symptoms, genetics.

\section{RESUMO}

Objetivo: A doença de Wilson (DW) é um erro inato do metabolismo causado por abnormalidades no gene ATP7B, que codifica uma proteína transportadora de cobre. Neste estudo, avaliamos as mutações do gene ATP7B em um grupo de pacientes do sul do Brasil. Métodos: Foram estudados 36 pacientes com DW e classificados do ponto de vista clínico e epidemiológico. Em 23 pacientes, o gene ATP7B foi analisado. Resultados: A substituição c.3207C>A no éxon 14 foi a mutação mais comum seguida pela mutação c.3402delC no éxon 15 . A mutação c.2018-2030 del13 no éxon 7 e a c.4093InsT no éxon 20 são relatadas pela primeira vez na literatura. Conclusão: A mutação do gene ATP7B, com a substituição c.3207C >A no éxon 14 foi a mais frequente. Esta mutação é a mais comumente encontrada em pacientes europeus.

Palavras-Chave: degeneração hepatolenticular, sinais e sintomas, genética.

In 1912, Wilson first described a familial disorder associated with neurological symptoms and cirrhosis ${ }^{1}$. Wilson's disease (WD) is an autosomal recessive inherited disorder of the copper metabolism. The ability to export copper from the liver into the bile and to incorporate copper into the hepatic caeruloplasmin is impaired.
As a consequence, this element accumulates in the liver, brain and corneas, resulting in highly variable clinical features, including chronic liver disease and/or neurological impairment ${ }^{2-4}$.

The gene defective in WD, ATP7B, that codes for a copper-transporting CPx-type ATPase ${ }^{3}$. ATP7B (locus 13q14.3)

\footnotetext{
Study carried out at Hepatology and Movement Disorders Unit, Internal Medicine Department, Hospital de Clínicas, Universidade Federal do Paraná (UFPR), Curitiba PR, Brazil and Department of Hepatology and Neurology, Universidade de São Paulo, São Paulo SP, Brazil.

${ }^{1}$ Gastroenterology and Hepatology Service, Internal Medicine Department, UFPR, Curitiba PR, Brazil;

${ }^{2}$ Center for Health and Biological Sciences, Pontifícia Universidade Católica do Paraná (PUC-PR), Curitiba PR, Brazil;

${ }^{3}$ Department of Hepatology and Gastroenterology, School of Medicine, USP, São Paulo SP, Brazil;

4Hepatology and Gastroenterology Tropical Laboratory, School of Medicine, USP, São Paulo SP, Brazil;

${ }^{5}$ Department of Neurology, School of Medicine, USP, São Paulo SP, Brazil;

${ }^{6}$ Neurology Service, Internal Medicine Department, UFPR, Curitiba PR, Brazil.

Correspondence: Hélio Afonso Ghizoni Teive; Rua General Carneiro 1.103 / 102; 80060-150 Curitiba PR - Brasil; E-mail: hagteive@mps.com.br

Support: Fundação de Amparo à Pesquisa do Estado de São Paulo (FAPESP), Process nº 06/00449-1.

Conflict of interest: There is no conflict of interest to declare.

Received 04 January 2013; Received in final form 11 January 2013.
} 
is a large gene, with 21 exons, spanning over a DNA region of approximately $100 \mathrm{~kb}$, and encoding a protein of 1,465 amino acids ${ }^{5}$. The ATP7B protein is expressed most abundantly in the liver, however, it has also been demonstrated in the kidney, brain, lung, heart, mammary gland, and placenta $^{6}$. In the hepatocytes, this protein delivers copper to apocaeruloplasmin and mediates the excretion of the cooper excess into bile ${ }^{2-4}$.

The worldwide prevalence of WD is estimated to range between 1 in 30,000 and 1 in 100,000, with a gene frequency of $0.56 \%$ and a carrier frequency of approximately 1 in $90^{7}$.

Currently, there are records of at least 400 distinct disease-causing mutations in the ATP7B gene that can be associated with $\mathrm{WD}^{8}$, including missense, nonsense, deletions, insertions, splice site and point mutations. While most of these mutations are rare and only reported in single families, some are clearly more common, accounting for a larger number of WD cases ${ }^{6}$.

In most ethnic groups, either one or a small number of ATP7B mutations are prevalent, followed by many other rare mutations. Knowledge of the regional distribution of WD gene mutations is important when designing the appropriate screening strategies ${ }^{9}$.

The study of the frequency of mutations is difficult in countries with a highly mixed population like the United States, the United Kingdom ${ }^{3}$, and Brazil. Deguti et al. ${ }^{10}$ evaluated the ATP7B genotype of 60 WD patients from different Brazilian regions, showing that the c.3402delC and the c. $2123 \mathrm{~T}>\mathrm{C}$ were the most common, representing nearly $50 \%$ of all the mutations in the country.

Therefore, to further understand the regional distribution of ATP7B mutations in Brazil, we focused our study to genetically analyze a WD population of southern Brazil characterized by a predominantly European ancestry.

\section{METHODS}

\section{Subjects}

A total of 36 subjects, including 20 females (56.6\%), with 34 white individuals (94,5\%), were diagnosed with WD in this sample. All patients were followed at the Units of Neurology and/or Gastroenterology at the Clinical Hospital of the Universidade Federal do Paraná, a reference center in Curitiba, Brazil.

The diagnosis of WD was based on a combination of typical neurological symptoms, liver disturbances, KayserFleischer rings, biochemical, histological and imaging tests. One asymptomatic subject was diagnosed through familial genetic screening.

The research was approved by the local Ethics Committee and informed consent was obtained from all subjects or from their parents before inclusion in the study.

\section{Clinical evaluation}

Patients were classified according to their age, gender, family history and the presence of consanguinity. Whenever available, data of patients' origin was obtained according to their knowledge of their furthest ancestral countries of origin. This information was later on classified as being purely European or a mixed European and undetermined Brazilian. Patients with the mixed ancestry were investigated to determine the possible presence of a native indigenous ancestor.

The age of the initial symptoms presentation was determined, and the time since the initial symptoms until the definitive diagnosis was calculated in months. Patient's clinical presentations were classified as predominantly hepatic, predominantly neuropsychiatric, mixed presentation (hepatic and neuropsychiatric) and asymptomatic.

\section{Mutation analysis}

In 23 of the 36 WD subjects the ATP7B gene was studied.

Genomic DNA was successfully extracted from whole blood samples collected in EDTA tubes at room temperature $\left(22^{\circ} \mathrm{C}\right)$ by a DNA extractor kit (QIA amp ${ }^{\circledR}$ DNA mini kit, Qiagen, Hilden, Germany).

The gene was amplified by PCR and the products of the reaction were subsequently purified using ExoSAP-IT (USB Corporation, Cleveland, USA) and direct sequencing was performed using a BigDye Terminator ${ }^{\circledR}$ in an automatic sequencer (Applied Biosystem, Darmstadt, Germany).

\section{RESULTS}

\section{Clinical evaluation}

The mean age was of $34.6 \pm 10.8$ (12-63) years. Mean age at the initial symptom presentation was $23.2 \pm 9.3$ (10-41) years. The mean time since the first clinical symptom and the definitive diagnosis was $27.5 \pm 41.9(1-194)$ months.

Family history was obtained in $16(44.4 \%)$ patients and only 2 individuals (5.5\%) described a history of parental consanguinity.

Data of patients' origin was available from 31 patients $(86.2 \%)$. All the original countries from their oldest known ancestors were accessed, being 16 (44.4\%) from Italy, 8 (22.2\%) from Poland, 8 (22.2\%) from Brazil, 7 (19.4\%) from Portugal, 5 (13.8\%) from Germany, 3 (8.3\%) from Spain, 3 (8.3\%) from Switzerland, 2 (5.6\%) from Ukraine, 1 (2.7\%) from Russia and $1(2.7 \%)$ from Ireland. This cohort of patients presented a high predominance of an exclusively European continental origin ( $n=23,74.2 \%)$. Eight $(25.8 \%)$ subjects reported mixed ancestry. Among them, 3 (37.5\%) identified the presence of a native indigenous ancestor.

Among the 36 WD patients, 9 (25\%) showed predominantly neuropsychiatric symptoms, 14 (38.9\%) predominantly hepatic symptoms, 11 (30.6\%) demonstrated both hepatic 
and neuropsychiatric features (mixed presentation) and 2 (5.5\%) were asymptomatic. The diagnosis among asymptomatic subjects was achieved through genetic family screening.

\section{Mutation Analysis}

Fourteen distinct mutations were detected in at least one of the alleles among 23 of the $36 \mathrm{WD}$ patients (Table 1). The c.3207C>A substitution at exon 14 was the most common mutation, with an allelic frequency of $37.1 \%$, followed by the c.3402delC at exon 15, with an allelic frequency of $11.4 \%$. These two different mutations account for about $48.5 \%$ of the alleles studied, thereby indicating that these exons are important regions for detecting mutations in southern Brazilian patients.

The c.3207C >A is the most common mutation described in Europe. Its frequency is higher in Poland and eastern Germany and decreases to the west and to the south, with an allelic frequency ranging between 30 and $70 \%$ (9). The c.3402delC is the most common mutation described for the Brazilian population, with an allelic frequency of $30.8 \%{ }^{10}$. Data of WD patients' continental origin and their ATP7B identified mutations are described in table 2.

According to the literature, the mutations c.20182030del13 at exon 7 and c.4093InsT at exon 20 are being

Table 1. Characteristics of ATP7B mutations.

\begin{tabular}{|c|c|c|c|c|}
\hline Nucleotide change & Amino acid & Variant type & Exon & Allele frequency $(n=35)$ \\
\hline c. $51+4 \mathrm{~A}-->T$ & & Insertion & Intron 1 & $1 / 2.85 \%$ \\
\hline c.1934T>G & Met645Arg & Substitution & 6 & $1 / 2.85 \%$ \\
\hline c. $2018-2030$ & & Deletion & 7 & $1 / 2.85 \%$ (new) \\
\hline c. $2123 T>C$ & Leu708Pro & Substitution & 8 & $1 / 2.85 \%$ \\
\hline c. 2304 delC & Met769CysfsX38 & Deletion & 8 & $1 / 2.85 \%$ \\
\hline c.2304dupC & Met769HisfsX26 & Duplication & 8 & $3 / 8.57 \%$ \\
\hline c. $2305 A>G$ & Met769Val & Substitution & 8 & $1 / 2.85 \%$ \\
\hline c. $2336 G>A$ & Trp779Stop & Substitution & 8 & $3 / 8.57 \%$ \\
\hline c. $2672 \mathrm{G}>\mathrm{T}$ & Gly891Val & Substitution & 11 & $1 / 2.85 \%$ \\
\hline c. $2762 G>A$ & Ser921Asn & Substitution & 12 & $1 / 2.85 \%$ \\
\hline c. $3207 C>A$ & His1069Gln & Substitution & 14 & $13 / 37.1 \%$ \\
\hline c.3402del C & Ala1135Glnfs & Deletion & 15 & $4 / 11.4 \%$ \\
\hline c. $3818 \mathrm{C}>\mathrm{T}$ & Pro1273Leu & Substitution & 18 & $2 / 5.71 \%$ \\
\hline c.4093InsT & & Insertion & 20 & 2/5.71\% (new) \\
\hline
\end{tabular}

Table 2. Patient ancestral's countries of origin and genotype correlation.

\begin{tabular}{|c|c|}
\hline ATP7B mutation & Patient ancestral's countries of origin \\
\hline heterozygote c.2762G>A & Germany, Poland \\
\hline heterozygote c.3207C>A & Native ancestor \\
\hline heterozygote c.3207C>A & Germany, Ireland, Italy, Native ancestor, Poland, Portugal \\
\hline homozygote c.3207C>A & Poland \\
\hline homozygote c.3207C>A & Switzerland \\
\hline homozygote c.3207C>A & Switzerland \\
\hline homozygote c.3207C>A & Switzerland \\
\hline homozygote c.3207C>A & Italy, Ukraine \\
\hline heterozygote c.3402delC & Brazil, Italy, Portugal \\
\hline heterozygote c.3402delC & Unknown \\
\hline homozygote c.3402delC & Brazil, Italy, Portugal \\
\hline homozygote c.3818C >T & Unknow \\
\hline heterozygote c.4093insT & Italy \\
\hline$[\mathrm{c} .4093 \mathrm{ins} T] /[\mathrm{c} .2672 \mathrm{G}>\mathrm{T}]$ & Italy \\
\hline [c.2336G>A]/[c.2018-2030del13] & Italy \\
\hline heterozygote c.2304delC & Poland \\
\hline heterozygote c.2305A>G & Italy, Poland \\
\hline heterozygote c. $2123 T>C$ & Unknow \\
\hline [c.2304duplC]/[c.3207C>A] & Germany, Italy, Poland \\
\hline homozygote c.2336G>A & Poland \\
\hline heterozygote c.2304duplC & Germany \\
\hline heterozygote c.2304duplC & Unknow \\
\hline$[$ Intron 1 c. $51+4 \mathrm{~A}-->\mathrm{T}] /[\mathrm{c} .1934 \mathrm{~T}>\mathrm{G}]$ & Italy, Portugal, Russia \\
\hline
\end{tabular}


reported for the first time ${ }^{8}$. These two novel mutations might be pathogenic, as both result in a deviation in transcription and thereafter lead to a complete stop in the transcription with the consequent formation of a truncated protein.

The first mutation (c.2018-2030del13) was detected in a 28 year-old female in whom the diagnosis of WD was suspected since age 16, when she came down with hemolytic anemia and hepatitis. Abnormal copper metabolism was detected by a combination of low serum levels of caeruloplasmin and elevated urinary levels of copper. Excellent clinical outcomes were achieved with D-penicilamine treatment. Genetic analysis disclosed a deletion of 13 base pairs at exon 7 (c.2018-2030del13) and a mutation leading to a stop in the transcription at exon 8 of gene ATP7B (c.2336G>A), thus confirming the diagnosis of WD on a molecular level.

The second mutation (c.4093InsT) was detected in a 22 yearold female, first admitted to the hospital with generalized edema, ascites and jaundice. Liver biopsy disclosed cirrhosis of unknown origin. The diagnosis of WD was suggested after clinical observation of Kayser-Fleischer rings and low serum-levels of caeruloplasmin. A relevant issue was that the patient is a firstdegree cousin of her husband. The results of direct sequencing revealed that the patient had an insertion mutation, which affects the genetic transcription at exon 20 (c.4093insT) and, in another allele, a substitution mutation of nucleotide at exon 11 (c.2672G>T), which, therefore, turns her into a compound heterozygote. The same analysis was performed in a DNA sample of her husband, which demonstrated that he is in turn heterozygote for the same mutation at exon 20 (c.4093insT), but not at the second allele, consequently an asymptomatic carrier of WD.

\section{Genotype-phenotype correlation}

The genotype-phenotype correlation analysis is described in Table 3. Subjects homozygous for the most common mutation $(n=5)$ had a mean age of disease onset of 33.4 4 4.82 years (median=33 years), compared to $15.7 \pm 3.21$ years (median $=17$ years) for heterozygotes $(n=3)$ and $19.5 \pm 8.55$ years (median=18 years) for the remaining individuals $(\mathrm{n}=15)$. All five homozygous subjects for the c.3207C >A had hepatic diseases, with three of them presenting both hepatic and neuropsychiatric symptoms.

\section{DISCUSSION}

This study analyzes the mutations of the ATP7B gene in a WD population from southern Brazil. Fourteen different mutations were found, reflecting the genetic heterogeneity of WD. The most common mutation in our sample was the c.3207C > A substitution at exon 14, followed by the c.3402delC at exon 15. These two different mutations account for about $48.5 \%$ of the alleles studied, about half of the mutations identified in this population. We also describe two novel potentially pathogenic mutations: c.2018-2030del13 at exon 7 and c.4093InsT at exon 20.

The c.3207C>A substitution at exon 14 represents 35 to $50 \%$ of the WD alleles affected in the European population $^{6}$. Its frequency is highest in Poland and eastern Germany and decreases to the western and to the southern European countries $^{9}$. The high rate of occurrence of this mutation in central and eastern Europe probably reflects the origin of this mutation in this very area ${ }^{11}$.

In Mediterranean countries there is a wide range of mutations, the frequency of each of them varies considerably from country to country ${ }^{9}$. In continental Italy, the c.3207C >A is the most common mutation, with an allelic frequency of $13-17 \%^{12}$.

The study of Deguti et al. ${ }^{10}$, published in 2004, was the first to genotype Brazilian WD patients. The authors determined

Table 3. ATP7B genotype and clinical characteristics in 23 Wilson's disease patients from southern Brazil.

\begin{tabular}{|c|c|c|c|c|c|}
\hline \multirow{2}{*}{ Genotype } & \multirow{2}{*}{$\begin{array}{l}\text { Index/non } \\
\text { index (n) }\end{array}$} & \multirow{2}{*}{$\begin{array}{l}\text { Mean age at onset/ } \\
\text { diagnosis (years) }\end{array}$} & \multicolumn{2}{|c|}{ Main affected organ } & \multirow{2}{*}{ Organs involved } \\
\hline & & & Liver (n) & Brain (n) & \\
\hline$[c .51+4 A>T] /[c .1934 T>G]$ & 1.0 & 41,44 & 0 & 1 & B \\
\hline$[\mathrm{c} .2336 \mathrm{G}>\mathrm{A}] /[\mathrm{c} .2336 \mathrm{G}>\mathrm{A}]$ & 1.0 & 15,16 & 1 & 0 & $L$ \\
\hline [c.2336G>A]/[c.2018-2030del13] & 1.0 & 15,15 & 1 & 0 & $L$ \\
\hline$[\mathrm{c} .2123 \mathrm{~T}>\mathrm{C}] /[-]$ & 1.0 & 18,21 & 0 & 1 & B \\
\hline$[\mathrm{c} .2304 \mathrm{delC}] /[-]$ & 1.0 & 12,19 & 1 & 0 & $B, L$ \\
\hline$[\mathrm{c} .2672 \mathrm{G}>\mathrm{T}] /[-]$ & 1.0 & 19,20 & 1 & 0 & $L, K$ \\
\hline [c.2304duplC]/[-] & 2.0 & 14,15 & 1 & 1 & $B, L, K$ \\
\hline [c.2304duplC]/[c.3207C>A] & 1.0 & 12,13 & 0 & 1 & B \\
\hline$[c .2762 G>A] /[-]$ & 1.0 & 26,27 & 1 & 0 & $L$ \\
\hline$[c .3818 \mathrm{C}<\mathrm{T}] /[-]$ & 1.0 & 34,36 & 0 & 1 & B \\
\hline$[c .3402 \mathrm{delC}] /[-]$ & 1.1 & $\mathrm{~A}, 12$ & 2 & 0 & $B, L$ \\
\hline [c.3402delC]/[c.3402delC] & 1.0 & 16,17 & 0 & 1 & B \\
\hline$[\mathrm{c} .4093 \mathrm{lnsT}] /[\mathrm{c} .2672 \mathrm{G}>\mathrm{T}]$ & 1.0 & 22,22 & 1 & 0 & $L$ \\
\hline [c.4093InsT]/[-] & 0.1 & A, 26 & 0 & 0 & A \\
\hline$[$ c.3207C>A]/[-] & 2.0 & 17,18 & 1 & 1 & $B, L$ \\
\hline$[\mathrm{c} .3207 \mathrm{C}>\mathrm{A}] /[\mathrm{c} .3207 \mathrm{C}>\mathrm{A}]$ & 3.2 & 33,36 & 2 & 3 & $\mathrm{~B}, \mathrm{~L}, \mathrm{~K}$ \\
\hline
\end{tabular}

A: asymptomatic; L: liver; B: brain; K: kidney. 
that the c.3402delC at exon 15 was the most common mutation, with an allelic frequency of $30.8 \%$. The second most frequent mutation was the c.2123T $>\mathrm{C}$ at exon 8 , with an allelic frequency of $14.1 \%$. The c.3207C $>$ A substitution at exon 14 was absent in the studied population ${ }^{10}$. These results differ dramatically from the ones reported here.

Characteristically, our study population from southern Brazil is composed mainly of subjects with a European ancestry. This is the reflection of the European colonization to this region during the XIX century, particularly from Germany, Poland and Italy ${ }^{13}$. It differs from the rest of the country, where a more mixed origin predominates, mostly due to a higher prevalence of Native Indigenous and African ancestors ${ }^{14}$.

Considering that Brazil is a continental country, the study of the frequency of WD mutations is difficult because of the inhomogeneity of the immigration. As determined for other countries such as India ${ }^{15}$, China ${ }^{16}$, and USA $^{17}$, the regional distribution of the WD mutations is important to be studied since these countries have a highly mixed population with diverse patterns of immigration.

Investigation of potential correlations between genotype and phenotype was hampered in this study by the rarity of most mutations and by the small number of subjects analyzed. However, we were able to demonstrate that patients homozygous for the c.3207C > A mutation were older at the time of symptoms onset and diagnosis. These findings confirm previous data on correlation of the c.3207C $>$ A mutation and the disease onset ${ }^{11,17}$.

On the other hand, we could not detect an association of the c.3207C>A mutation with predominantly neurological manifestations, as described by Caca et al. ${ }^{11}$. Other groups also failed to demonstrate this correlation ${ }^{17,18}$. The lack of consensus in the literature regarding this issue could be explained by the observations that clinical manifestations of WD are heterogeneous even in patients carrying the same mutation. It is, therefore, hypothesized that other additional genetic and/or environmental factors could influence the phenotypes of WD, such as dietary cooper intake, metallothionein inducibility, the individual capacity to handle copper overload, the ApoE genotype, human prion gene polymorphism and mutations in COMMD1 1,17,19-22.

In conclusion, the results of the present study improve the knowledge of the molecular diagnosis of WD patients from southern Brazil. Almost half of the mutations of the ATP7B gene were located at exons 14 and 15. Consequently, the identification of these most prevalent mutations provide basis to design appropriate regional screening strategies for the genetic diagnosis of WD.

\section{References}

1. Walshe JM. Wilson’s Disease. New oral therapy. Lancet 1956;1:25-26.

2. Tanzi RE, Petrukhin K, Chernov I, et al. The Wilson disease gene is a copper transporting ATPase with homology to the Menkes disease gene. Nat Genet 1993;5:344-350.

3. Bull PC, Thomas GR, Forbes J, Rommens JM, Cox DW. The Wilson disease gene is a putative copper transporting p-type ATPase similar to Menkes gene. Nat Genet 1993;5:327-337.

4. Yamaguchi Y, Heiny ME, Gitlin JD. Isolation and characterization of a human liver cDNA as a candidate gene for Wilson disease. Biochem Biophys Res Commun 1993;197:271-277.

5. Petrukhin KE, Lutsenko S, Chernov I, et al. Characterization of the Wilson disease gene encoding a P-type copper transposting ATPase: genomic organization, alternative splicing, and structure/function predictions. Hum Mol Genet 1994;3:1647-1656.

6. Behari M, Pardasani V. Genetics of Wilson's disease. Parkinson Relat Disord 2010;16:639-644.

7. Ala A, Walker AP, Ashkan K, Dooley JS, Schilsky ML. Wilson's disease. Lancet 2007;369:397-408.

8. Kenney SM, Cox DW. Sequence variation database for the Wilson disease copper transporter, ATP7B. Hum Mutat 2007;28:1171-1177.

9. Ferenci P. Regional distribution of mutations of the ATP7B gene in patients with Wilson disease: impact on genetic testing. Hum Genet 2006;120:151-159.

10. Deguti MM, Genschel J, Cançado ELR, et al. Wilson disease: novel mutations in the ATP7B gene and clinical correlation in Brazilian patients. Hum Mutat 2004;398:1-8.

11. Caca K, Ferenci $P$, Kühn HJ, et al. High prevalence of the $\mathrm{H} 1069 \mathrm{Q}$ mutation in East german patients with Wilson disease: rapid detection of mutations by limited sequencing and phenotypegenotype analysis. J Hepatol 2001;35:575-581.

12. Loudianos G, Dessi V, Lovicu M, et al. Further delineation of the molecular pathology of Wilson disease in the Mediterranean population. Hum Mutat 1998;12:89-94.
13. Corrêa LS. As políticas públicas de imigração européia não portuguesa para o Brasil - de Pombal à República. Rev Geo Paisagem 2005;4:8.

14. Instituto Brasileiro de Geografia e Estatística (IBGE). Brasil 500 anos de povoamento. Rio de Janeiro: IBGE, 2000.

15. Gupta A, Aikath D, Neogi R, et al. Molecular pathogenesis of Wilson disease: haplotype analysis, detection of prevalent mutations and genotype-phenotype correlation in Indian patients. Hum Genet 2005;118:49-57.

16. Mak CM, Lam CW, Tam S, et al. Mutational analysis of 65 Wilson disease patients in Hong Kong Chinese: identification of 17 novel mutations and its genetic heterogeneity. J Hum Genet 2008;53:55-63.

17. Shah AB, Chernov I, Zhang HT, et al. Identification and analysis of mutations in the Wilson disease gene (ATP7B): population frequencies, genotype-phenotype correlation, and functional analyses. Am J Hum Genet 1997;61:317-328.

18. Thomas GR, Forbes JR, Roberts EA, Walshe JM, Cox DW. The Wilson disease gene: spectrum of mutations and their consequences. Nat Genet 1995;9:210-217.

19. Panagiotakaki E, Tzetis M, Manolaki N, et al. Genotype-phenotype correlations for a wide spectrum of mutations in the Wilson disease gene (ATP7B). Am J Med Genet 2004;131:168-173.

20. Schiefermeier M, Kollegger H, Madl C, et al. The impact of apolipoprotein $\mathrm{E}$ genotypes on age of onset of symptoms and phenotypic expression in Wilson's disease. Brain 2000;123:585-590.

21. Merle U, Stremmel W, Gessner R. Influence of homozygosity for methionine at codon 129 of the human prion gene on the onset of neurological and hepatic symptoms in Wilson disease. Arch Neurol 2006;17:549-552.

22. Gupta A, Chattopadhyay I, Mukherjee S, et al. A novel COMMD1 mutation Thr174Met associated with elevated urinary copper and signs of enhanced apoptotic cell death in a Wilson disease patient. Behav Brain Funct 2010;6:33. 